IBAD, 2019;(5): 1-8

\title{
The Unfortunate Triumph of Anthropocentrism over the Carnivalesque In William
}

Golding's The Lord of the Flies

\section{Öğr. Gör. Dr. Özlem Akyol}

Geliș tarihi: 10.05.2019

Kabul tarihi: 14.06 .2019

\section{Atıf bilgisi:}

IBAD Sosyal Bilimler Dergisi

Sayı: 5 Sayfa: $1-8$

Yıl: 2019 Dönem: Güz

This article was checked by Turnitin. Similarity Index 10\%

\footnotetext{
1 Pamukkale Üniversitesi, Türkiye, ozlemakyol12@gmail.com ORCID ID 0000-0002-0641-8710
}

\section{* Sorumlu yazar}

\section{$\ddot{O Z Z}$}

Rus kuramcı ve felsefeci Mikhail Bakhtin kuramsal çerçevesini çizdiği karnaval kavramı 1930'lardan beri oldukça önem kazanmıştır. Karnaval kavramını sadece bir festival etkinliği olarak tanımlamak yerine, Bakhtin kavrama evrensel bakışıcısı ve ritualistik bir özellik atfetmiştir. Bu şekilde, karnaval ruhu değişiklik ve kriz; doğum ve ölüm; gençlik ve yaşlılık; övgü ve yergi gibi kavramları içinde barındıran ikilemli doğasıyla oldukça kapsamlı bir kavrama dönüşür. Karnaval kavramının bu şekilde kapsamlı olması genel kabul gören normların ortadan kaldırılmasına bunun yerine dünyanın sonsuz olanaklı olma özelliği, yeniden yaratma, ölüm doğum döngüsü gibi dünyayı bir bütün olarak gören fikirleri benimsemesine neden olur. Bu bütünleştirici bakış açısı aynı zamanda tüm sosyal, dinsel ve politik olarak biçimlenmiş rollerin, normların ve geleneklerin yıkılması anlamına gelir. Buna bağlı olarak da aynı bakış açısı karnavalın katılımcılarına doğanın iklimsel ve bitkisel döngüsüyle iç içe geçme firsatı verir. Her türlü norm ve kuraldan arındırılmış bu özel zaman dilimi direk olarak insanoğlunun temel güdülerine hitap eder. Bu durum 1ssız bir adaya düşmüş bir grup okul çocuğunu ve onların orada bir topluluk oluşturma çabalarını konu alan William Golding' in Lord of the Flies adlı eserinde açıkça resmedilmiştir. Ancak insanların temel güdülerine dönmesi aynı zamanda iklimsel ve bitkisel döngüyle iç içe geçmeleri bakımından doğa ile ilişkilendirilen karnaval ruhu adanın yeni sakinlerinin antroposentrik uygulamaları yüzünden kaybolmaya mahkûm olmuştur. $\mathrm{Bu}$ makale Lord of the Flies adlı romanda karnaval kavramının antroposantrizm tarafindan nasıl alaşağı edildiğini göstermeyi amaçlar.

Anahtar Kelimeler: Bakhtin, karnaval kavram1, antroposantrizm, Lord of the Flies. 


\section{The Unfortunate Triumph of Anthropocentrism over the Carnivalesque In William}

\section{Golding's The Lord of the Flies}

\section{Lec. Dr. Özlem Akyol}

First received: 10.05 .2019 Accepted: 14.06 .2019

\section{Citation:}

IBAD Journal of Social Sciences

Issue: $5 \quad$ Pages: $1-8$

Year: 2019 Session: Fall

This article was checked by Turnitin. Similarity Index 10\%

\footnotetext{
${ }^{1}$ Pamukkale Universitiy, Turkey, ozlemakyol12@gmail.com ORCID ID 0000-0002-0641-8710
}

* Corresponding Author

\begin{abstract}
The carnivalesque has acquired substantial importance within Russian theorist and philosopher Mikhail Bakhtin's theoretical framework since 1930s. Instead of defining carnival as mere a festive event, Bakhtin ascribes a ritualistic and universal meaning to the concept. As such, carnival spirit is so comprehensive with its dualistic nature containing change and crisis; birth and death; youth and old age; praise and abuse within itself. All these symbolic strategies are designed to overthrow the generally accepted norms but celebrate open-ended qualities of the world, regeneration, the cycles of birth and death, which marks the cosmos as a whole. This holistic approach simultaneously deconstructs all kinds of socially, religiously and politically fixed roles, norms and traditions and accordingly enables participants to intertwine with the vegetative and climatic cycles of nature. The exclusive time period deprived of any kind of rules and norms directly refers to the basic instincts of human being. Such spirit is apparently illustrated in William Golding's Lord of the Flies (1954) which focuses on a group of schoolboys stranded on an inhabited island and their attempt to set up a community there. However, the carnival spirit which is associated with nature regarding human being's return to their basic instincts as well as his interaction with climatic and vegetative cycles dooms to fail due to the anthropocentric practices performed by the new inhabitants of the island. The novel is a unique example to demonstrate the effects of anthropocentrism since the setting is an uninhabited island initially deprived of human intervention. In this respect, the present paper aims to demonstrate how the carnivalesque is overthrown by anthropocentrism in Lord of the Flies.
\end{abstract}

Keywords: Bakhtin, the carnivalesque, anthropocentrism, Lord of the Flies. 
The carnivalesque which is characterised by Bakhtin in Rabelais and His World (1965) contains rituals, games, symbols and various carnal excesses that form an alternative social space of equality, abundance and freedom. Bakhtin describes the carnival spirit as "syncretic pageantry of ritualistic sort," which expresses a "general world outlook" (Bakhtin, 1984: 435). Therefore, the concept turns out a social-cultural phenomenon rejecting the "serious tone of medieval ecclesiastical and feudal culture" and also deconstructs the ideology of dominant culture (Bakhtin, 1984: 4). As cultural historian Peter Burke clearly asserts the carnival itself was often personified as nature and the festive period was universally considered to be the time when the normal rules of civilization were suspended or overturned (1978: 187). While elaborating carnival, Bakhtin claims that "As opposed to the official feast, one might say that carnival celebrated temporary liberation from the truth and from the established order; it marked the suspension of all hierarchical ranks, privileges, norms and prohibitions. Carnival was the true feast of time, the feast of becoming, change and renewal. It was hostile to all that was immortalized and completed" (1984: 10). According to him, during the carnival the ideology of the dominant culture and all kinds of social, political and religious hierarchies are turned upside down temporarily, which renders all participants equal.

The carnivalesque comprises different key concepts one of which is carnival laughter. Perceived as the humorous side of carnival, carnival laughter is very important since it is usually described as the basis of carnival. It belongs to the carnivalesque space which can be defined as a short-term utopia or as Morris states it is "a second reality outside the official realm" (1994: 194). The carnival laughter bears some peculiar characteristics; firstly, it is characterised as a group activity rather than being an individual act, secondly, it is in universal scale which means any person from different classes and backgrounds are allowed to join it because of the deconstruction of all hierarchical systems, finally, as Bakhtin asserts "this laughter is ambivalent" (Bakhtin, 1984: 11), which comes to mean that it is not only victorious and happy but also mocking and sarcastic. Another key concept related to carnival is grotesque body or grotesque realism which refers to excessive images of human being and body claiming that this imagery represents the "collective ancestral body" rather than "the isolated biological individual" or "private, egotistic, economic man" (Bakhtin, 1984: 19). He also claims that the universal grotesque body imagery tends to degrade the high and the ideal to the bodily and material level which comes to mean that renewal of the body only comes after the process of degradation, in other words, degradation brings down the body to the level of rebirth. Grotesque symbolism, therefore, apparently denies the possibility of completion and finality but it illustrates the body open and unfinished in such a way that it continuously merges with other non-human entities. In this sense, carnival spirit is in a constant interaction with nature. Images related to the carnival are usually mocking and cheerful fusion of vegetable, animal and human configuration or transformation of one into another. This fusion functions to reverse the alienation of human beings from nature strengthened by any hierarchical systems to refamiliarization of human beings with the natural world. As Bakhtin argues during the carnival "the borderlines that divide the kingdoms of nature in the usual picture of the world were boldly infringed" (Bakhtin, 1984: 32).

The alienation of human being from nature and accordingly the deepening gap between nature and culture is one of the environmental problems of the modern age. This rupture basically stems from anthropocentric point of view of human being. Anthropocentrism, or human-centeredness, is widely acknowledged as a central concept in environmental philosophy, where it is used to draw attention to a systematic and unjustified bias in traditional Western attitudes to the nonhuman world (Naess, 1973). This pervasive attitude in which human being is seen as inherently superior to other species and ecosystems has influenced the ways humans interact with nature. As Rob Boddice states that anthropocentrism "is expressed either as a charge of human chauvinism or as an acknowledgement of human ontological boundaries. It is in tension with nature, the environment, and non-human animals. [...] Anthropocentrism has provided order and structure to humans' understanding of the world, while unavoidably expressing the limits of that understanding. It influences our ethics, our politics, and the moral status of the others" (2011: 1). According to ecologists, the present environmental crisis can only be mitigated through a revolutionary shift from an anthropocentric or human centred perception to more eco-centric point of view. Today, anthropocentrism has accelerated based on different social, historical, 
political and epistemological factors: growth-oriented economic system, developments in science and technology resulting in overuse of natural resources; deepening of social hierarchies related to gender, ethnicity, race and class; exploitive attitude of the first world towards the third world countries and so on. To alleviate this situation, it is essential to reconsider the established patterns of production, consumption, technology and also physical and psychic position of human being in the whole ecosystem. The eco-centric ethos would give priority to the interaction of human beings with nature and also show that there is no absolute distinction between human and non-human beings. In this point, Bakhtin's carnival undoubtedly demonstrates a number of qualities serving to eco-centric insight such as deconstruction of fixed and hierarchical roles, interconnectedness of human beings with nature, denial of fixity and celebration infinity. Therefore, Bakhtinian carnival is assumed to stand against anthropocentric practices which is often considered as the origin of human induced problems within the ecosystem.

Despite not being basically categorized as an ecological text, Lord of the Flies set in inhabitant heaven-like natural environment has been analysed from eco-critical point of view many times. In the novel, William Golding, who experienced two world wars and their destructive effects on people and also on environment during his life, illustrates an alternate realm in a remote and virgin island inhabited by a group of school boys who are stranded on this island following a shipwreck. In the beginning, the novel can be perceived as an adventurous children book analogous with Ballantyne's Coral Island. Lord of the Flies, however, explicitly goes beyond this category because of Golding's profound usage of symbolic imagery and also his skilful representation of real life issues like passion for power, discrimination, ignorance for nature or human centeredness and so on. The author draws two completely opposing panoramas for the island; the first image is when the children arrive in the island, which is a dreamlike place with its natural beauties and abundant natural sources and, the second one is when they leave the island behind as a complete natural ruin. Using this disastrous environmental imagery, Golding reveals how human being, seemingly innocent children in this particular case, transforms into barbaric creature ravaging everywhere and everything by ignoring intrinsic values of non-human beings on the island.

The carnivalesque in Lord of the Flies is basically narrated through the temporary exclusion of stable and ordered patterns of social life. Rules, taboos and social norms are replaced by desires and drives which have been repressed by individuals under the effect of social, religious, political and dogmatic enforcements. In the beginning of the novel, as soon as the boys gather on the island, one of them picks up a large conch from the beach and together they decide that anybody who holds it should have the right to speak. In this way, the conch becomes a kind of institutional mechanism regulating the small community on the island. Choosing the conch as a regulating mechanism can be read as the deconstruction of nature and culture opposition, which is one of the main issues ecocriticism principally engages with. This means that the carnival spirit on the island offers the boys more liberal and equalitarian regulating mechanism than they used to be exposed before they come to the island. However, the conch is soon identified with its material value by Piggy when he says that "a conch; ever so expensive. I bet if you wanted to buy one, you'd have to pay pounds and pounds and pounds - he had it on his garden wall, and my auntie" (LofT, 174). Piggy's attitude implies human being's tendency to materialize nature and not to include intrinsic values of non-human beings within his own ethos. As it is seen the peaceful carnival atmosphere starts to shatter when the boys are grouped under the command of two leaders; Jack and Ralph. The former one is mostly associated with fascism and savagery, on the other hand, the latter is more liberal and democratic. These two groups do not live in peace any longer. As Golding states "The world, that understandable and lawful world was slipping away" (LofT, 98). The things get worse when Jack and his crew gain more power and take the total control of the island.

As well as being a place which is dominated by the chaos between these groups, the island also hosts various conflicting characters, which refers to the element of multiplicity in Bakhtin's world of carnival. Golding's allegorical character formation introduces reader with a rich set of characters each of whom is unique and reflecting a particular aspect of human nature. Ralph, for example, who is the protagonist of the novel, represents law, democratic society and favours priority of the group rather than his selfish desires. In contrast, Jack is a character whose tyrannical malevolence dethrones Ralph's authority and turns himself into a savage obsessed with the idea of absolute power over human and non- 
human beings around him. Apart from these two main characters, Piggy is another character who is marked with his scientific and rational point of view and Simon is identified with his strong intuitive ability. The variety of characters is the sign of multiplicity which is one of the features of carnival spirit. In this sense, Bakhtin's carnival where different voices blend together is brought into action in the beginning of the novel. About the multiplicity which is also known dialogism, Michel Foucault asserts that it "extends our participation in the present system" (1984: 45). Through dialogism, new possibilities for each different voice may occur and this ends up with revelation hidden potentials. According to Bakhtin, "Dialogism is a fundamental aspect of the carnival - a plurality of 'fully valid consciousnesses'" (1984: 9). He argues that by excluding yourself from your own culture and simultaneously being exposed to another, you are more likely to understand your own culture better. Moreover, as the carnival is the time undermining the hegemony of any ideology, groups alienated by a dominant ideology during non-carnival time are able to speak out and also have a right to criticise the ideological system that has silenced them so far. Nevertheless, the multiplicity formed by a number of metaphorical characters in Lord of the Flies causes conflict and discrimination rather than "making it possible to extend the narrow sense of life" (Bakhtin, 1984: 177). Instead of being an opportunity to enrich the vision of community and posing a challenge to the dominant ideology which is represented through Jack in the novel, the other characters corresponding to different voices are eliminated one by one by Jack and his crew. In the end of the novel, Jack, who is "liberated from shame and selfconsciousness" transforms into a creature whose "laughter became a bloodthirsty snarling" in order to exert his own ideology.

Besides Jack and his crew's brutal hegemonic practices and their tragic consequences, the natural world on the island is also irrevocably damaged. At first, Golding so impressively describes the island as a place of enchanting beauty and peaceful atmosphere that even these school boys at their young age are charmed by the utopic beauty of the island. Ralph defines their new habitat as the "imagined but never fully realized place leaping into real life" (Lof $T, 11)$. Golding continues to give some details about the island and simultaneously makes some implications for the future of the place when he writes "The shore was fledged with palm trees. These stood or leaned or reclined against the light and their green feathers were a hundred feet $\mathrm{u}$ in the air. Their ground beneath them was a bank covered with coarse grass, torn everywhere by the upheavals of fallen trees, scattered with decaying coconuts and palm saplings. Behind this was the darkness of the forest proper and the open space of the scar" (LofT, 4). In the author's description of the natural surroundings, it can be understood that he ascribes a pure and heavenly meaning to the island by describing it as an untouched and uninhabited place far from civilization. The forest is described as a dark place because of the tall trees that create huge shadows. At the same time, he foreshadows the threat that the place is going to face with when he writes "the darkness of the forest", which implies the fire destroying the place at the end of the novel. Moreover, "the open space of the scar" is frequently referred in the novel, which stands for the permanent disruption in nature. As a matter of fact, the scar alludes to the rip in the forest caused by the plane crash, yet it symbolizes the sudden and violent arrival of human beings to the island and their intervention in nature. This intervention becomes an indelible indication of the destruction that the boys have caused. The damage and the chaos are strikingly described by Golding when he relates the last scene in which Ralph is chased by the boys with spears to kill him, "His voice rose under the black smoke before the burning wreckage of the island; and infected by that emotion, the other little boys began to shake and sob too. And in the middle of them, with filthy body, matted hair, and unwiped nose, Ralph wept for the end of innocence, the darkness of mans heart, and the fall through the air of the true, wise friend Piggy" (LofT, 202). The end of the novel is the explicit portrayal of anthropocentric attitude of human being. In their article entitled "Ecocritical Reading of Lord of the Flies", Thapliyal and Kunwar assert "This anthropocentric human leaves nature shuddering in flame. This approach makes man claim everything for him, forgetting that nature is a separate self-balancing entity" (2011: 85).

One of the key concepts of the theory, the carnival laughter is mostly represented in the novel through the most reasonable and scientific character, Piggy, especially through the attitude of his friends towards him. Piggy is identified as a humorous character with his asthma, weight and poor eyesight which give him physically inferior appearance and also make him vulnerable to scorn and ridicule. He 
rather represents the scientific and rational aspects of life. He first suggests lighting a signal fire on the island, and he even plans about creating a sundial through which they can be aware of time. Piggy's authenticity and peculiarity prevent him from being fully absorbed by the group and accordingly he is frequently mocked by the mob in humorous way. One of the symbols on the island is Piggy's glasses which are essential both for him and to make a signal fire to attract any ships nearby. In this sense, the glasses symbolize their hope to be rescued and also civilization since fire is frequently associated with a civilized society. Therefore, they start to use "his specs [...] as burning glass" (LofT, 52). Once, Jack lets the fire off as he is in the pursuit of hunting the pig. On his return with triumph, he is yelled by Ralph, Piggy and even some of the hunters. He responsively "smacked Piggy's head. Piggy's glasses flew off and tinkled on the rocks" (LofT, 52), which causes breaking one of the lenses of his glasses. Jack and the hunters feel victorious and mock and laugh at Piggy in frenzy. This scene which is associated with the idea of the carnival laughter also contains sarcasm and humiliation. As the mob laugh at the ridiculous position that Piggy is in, science and rationalism which are represented by the glasses are simultaneously undermined and mocked. Carnival laughter contains ambivalent abuses which look humiliating and mortifying. As Bakhtin states, "its meaning underwent essential transformation; it lost its magic and its specific practical direction and acquired an intrinsic, universal character and depth. In this new form abuse contributed to the creation of the free carnival atmosphere, to the second droll aspect of the world" (1984: 5).

Carnival laughter is theorized as "not an individual reaction to some isolated 'comic' event [but] the laughter of all the people [...] It is universal in scope; it is directed at all and everyone, including the carnival's participants" (Bakhtin, 1984: 11). It blurs the borders between actors and spectators accordingly turns out a kind of rave which is defined as an enthusiastic social gathering usually accompanied by dance. Carnival laughter is materialized through the rave in which all ecstatic participants perform rituals, games, dances and various carnal excesses. "In the carnivalesque game of inverting official values, [participants] see the anticipation of another, utopian world in which antihierarchism, relativity of values, questioning of authority, openness, joyous anarchy, and the ridiculing of all dogmas hold sway, a world in which syncretism and a myriad of differing perspectives are permitted. (Lachmann et.al, 1989: 118). In Lord of the Flies, Jack and the other hunters gather on the beach and give a feast with the pig they have just hunted. During the feast, they experience such a frenzied mood that intrinsic nature of human body is revealed. In other words, the rave on the beach can be read as the representation of such an attitude that the participants refute the rules of domesticated urban life and accordingly they act with the motive of primitive drives embedded in human nature. In doing so, this party is supposed to be a platform for freedom and abundance and also where all the restrictions are suspended. However, the party ends with the unfortunate death of Simon. During the event, the pig hunting scene is re-enacted by the boys one of whom pretends like a pig and the others attack to kill him. In this frenzy, Simon, who is "so decent, so selflessly behave, so opaquely meditative, so unjustly executed" (Olsen, 2000: 15) that he is frequently identified with Christ, is killed after having learned the truth about the beast that it is actually the corpse of a man with parachute. Situated as a holy figure in the story, Simon is slaughtered by the mob, which shows the carnival laughter changes into a tragedy due to Jack and his group's self-centred and discriminatory performances.

In line with Bakhtin's carnival, there is another key point called grotesque realism which mainly draws on the idea of grotesque aiming at bringing elevated phenomena to the material or bodily level. According to Bakhtin, such images show "human body is not individualistic; on the contrary it is a universal concept which represents all-people's character" (1984: 19). Based on these two different characteristics, the Biblical term Beelzebub, a powerful demon figure also known in the novel as the Lord of the Flies that is literally a bloody pig's head cut and impaled on a stake by Jack corresponds to the idea of grotesque realism. This metaphoric figure becomes the most important image in the novel when Simon hallucinates that it tells him evil lies in every human heart. Therefore, the Lord of the Flies becomes a kind of unearthly and sacred figure which is mostly feared but at the same time respected by the community it dominates.

Lord of the Flies which is attributed a god-like meaning represents the idea that grotesque realism brings the concept of god to the material level. This profanation is a deliberate practice of 
grotesque realism aiming at questioning and deconstructing the absolute position of god in human mind. However, the consequence of this attitude is completely different in the novel. Lord of the Files is a crucial figure with such a hallucinating effect on Simon that their encounter in the forest changes the course of the events in the narrative. As Simon returns after learning the truth about the beast, he encounters the Lord of the Flies in the forest. At that moment, Simon hallucinates that it is talking to him "Fancy thinking the Beast was something you could hunt and kill! You knew didn't you? I'm part of you? Close, close, close! I'm the reason why it's no go? Why things are what they are?" (LofT, 143). The grotesque body which is also characterised as "collective ancestral body" underlines universal human traits. As such, the Lord of Flies speaks of evil side in human nature which is claimed to be the absolute reason for all catastrophe on the island. According to Bakhtin, profanation sustained by grotesque realism is a good way to deconstruct the absolute position of god in human mind in order to regenerate a genuine and naïve spiritual belief. Moreover, grotesque realism elaborates universal aspect of human beings rather than covering individualistic traits, which makes the idea encompassing and timeless. Therefore, grotesque realism could be a kind of warning in order to question dogmatic beliefs in human mind and also, it attracts all people from different regions, nationalities, ethnicities, religions or genders when the universal aspect of the idea is considered.

Contrary to expectations, in the novel grotesque realism mostly conveyed by the figure of Lord of the Flies has completely different consequences. This grotesque figure becomes the embodiment of Jack and his crew's anthropocentric practices. After the boys on the island are divided into two groups under the leadership of Jack and Ralph, Jack and his crew become too obsessed with hunting. They devote themselves to this task so firmly that they transform into barbarian and bloodlust creatures. They not only cause the death of Simon and Piggy and also damage the environment completely ignoring the intrinsic values of non-human beings. Apart from Ralph, Simon and Piggy, the rest of the boys follow Jack's savage and violent practices. Jack manipulates the boys by using their fear of the beast. In this sense, Jack's power is materialised through Lord of the Flies. Therefore, Bakhtin's grotesque realism is denied in the novel. Instead, Lord of the Flies illustrated as the figure of grotesque realism becomes the symbol of power manipulating communities rather than leading them to the research in the pursuit of reality.

The features of the carnival like its potential to suspend social norms and rules enforced by hegemonic systems and its capacity to embrace different voices which is called the multiplicity spontaneously exist in the beginning of the novel. Additionally, carnival laughter and grotesque realism which are the basic elements of the theory are represented through different symbols and characters throughout the novel. In this sense, the life on the island that the boys are initially exposed to is an allusion to Bakhtin's carnival which subverts "the uniform, fixed and hierarchical world view of rationalism" (Dentith, 1999: 79). Accordingly, the boys are supposed to have life of freedom and abundance without being restricted by any hegemonic system and supervision of adults. When one of the boys surprisingly finds out "there aren't any grownups anywhere" they feel free without restrictions their parents, school and the law. Nevertheless, "the taboo of the old life is invisible yet strong" among kids therefore, they cannot help themselves to imitate their grownups and accordingly end up with a real catastrophe. Piggy shows his loyalty to their grownups' attitude when he says "We did everything adults would do. What went wrong?" after Simon is murdered by Jack and his crew. At this point, Piggy cannot cope with the feeling of being constrained by the institutions and the figures that are assumed to have hegemonic power on his life. This indicates that the carnival spirit cannot be sustained and dooms to fade away gradually.

The gradual disappearance of the carnival spirit on the island is directly correlated with the enforcement and implementation of anthropocentric worldview. In the novel, as the plot unfolds, the boys start to act in the pursuit of their well-being and accordingly become so insensitive to the intrinsic value of the non-human beings on the island that they even do not hesitate to set all the forest on fire. The idea that human being is superior to the non-human strengthens the idea of distinction which is completely opposed to the carnival spirit since Bakhtin believes that the carnival "is a special condition of the entire world, of the world's revival and renewal, in which all take part." (1984: 7-8). Believing in their mastery over nature the boys let the carnival spirit which would probably offer them a life of 
equality and abundance be overthrown by anthropocentrism causing irreversible environmental damage on the island. Anthropocentrism will most probably drag human being to his tragic end as it is seen in

Lord of the Flies as long as anthropocentric practices are allowed to continue and their deleterious effects are disregarded.

\section{REFERENCES}

Bakhtin, M. (1984). Rabelais and his world. USA: Indiana University Press.

Burke, P. (1978). Popular culture in early modern Europe. USA: New York University Press.

Boddice, R. (2011). Anthropocentrism: Humans, animals, environments. Boston: Brill.

Dentith, S. (1995). Bakhtinian thought: An introductory reader. UK: Routledge.

Foucault, M. (1984). What is enlightenment? Ed. in The Foucault reader. New York: Pantheon Books. $32-50$

Golding, W. (1954). Lord of the flies. New York: The Berkley Publishing Group.

Kidd, K. (2004). Wild things: Children's culture and ecocriticism. USA: Wayne State University Press.

Lachmann, R., Eshelman, R., \& Davis, M. (1989). Bakhtin and carnival: Culture as counter-culture. Cultural Critique, University of Minnesota Press, No. 11, pp. 115-152. Stable URL: https://www.jstor.org/stable/1354246

Morris, Pam. (1994). The Bakhtin reader: Selected writings of Bakhtin, Medvedev, Voloshinov. London: Arnold Print.

Naess, Arne. (1973). The shallow and the deep, long-range ecology movement. Inquiry, 16, 95-100.

Olsen, K. (2000). Understanding lord of the flies. London: Greenwood Press.

Thapliyal, R. and Kunwar, S. (2011). Ecocritical reading of William Golding's lord of the flies. The IUP Journal of English Studies, 1, 85-90. 